\title{
COMPARATIVE LITERATURE STUDIES
}

DOI https://doi.org/10.30525/978-9934-588-90-7-47

\section{ТРАКТУВАННЯ ОБРАЗУ ЖАННИ Д'АРК В УКРАЇНСЬКІЙ МАЛІЙ ПРОЗІ ПЕРШОЇ ПОЛОВИНИ ХХ СТ.}

\author{
Бойченко О. I. \\ аспірант кафедри світової літератури \\ Львівський національний університет імені Івана Франка \\ м. Львів, Україна
}

Загально-значимі процеси i протиріччя в історичному розвитку людства мають здатність повторюватися, а це зумовлює звернення до попередньо створених сюжетно-образних структур. Така повторюваність у реальному житті $\epsilon$ причиною повторюваності в літературі та звернення у ній до традиційних образів і сюжетів. Ці сюжети і образи стають поштовхом для нових переоцінок дійсності в залежності від потреб і обставин нових століть. У цьому сенсі вони залишаються сучасниками наступних епох. Окрім того, подібні сюжети та образи вільно мігрують і в міжлітературному та, ширше, міжкультурному просторі.

Оскільки кожен автор, що у своїй творчості звертається до традиційних образів чи сюжетів, все ж залишається носієм ментальності свого народу, доцільно говорити про пристосування інонаціонального образу чи сюжету, вибраного автором, до конкретного національного культурного контексту. У статті «Аспекти входження «вічних» сюжетів у національну літературу» літературознавець Марина Шевчук зазначає, що: «у будь-якому випадку «вічний» сюжет-першоджерело завжди $\epsilon$ чужим (екзотичним) щодо конкретної національної літератури, в яку він входить шляхом переробки. Ця інакшість позанаціонального сюжетно-образного матеріалу підпадає при його трактуванні під певні механізми оригінального та органічного засвоєння або «націоналізації» (термін М. Грушевського)» [4, с. 48].

Націоналізацію М. Шевчук визначає як вияв певних національноспецифічних чинників у процесі адаптації традиційних сюжетів у новому культурно-історичному середовищі, що призводить до зміни структурносемантичних, функціональних і психо-поведінкових параметрів традиційного матеріалу, до заміщення його мотиваційно-ціннісних домінант $\mathrm{i}$ трансформації змісту, наголошуючи на тому, що націоналізація тради170 
ційного сюжету, зазначає М. Шевчук, відбувається через включення його в оригінальну етнокультуру [5, с. 13].

Для входження у новий контекст та новий культурний простір традиційні сюжети вимагають специфічних умов, а звідси повинні відбутися певні адаптаційні процеси, які передбачають трансплантацію традиційного сюжетно-образного матеріалу на інший національний грунт, що, власне, і $є$ націоналізацією таких образів і сюжетів у просторі літератури-реципієнта, культури-реципієнта.

3 огляду на сказане вище, не можемо не ствердити, що у зв'язку із культурно-історичними умовами, які склалися в Україні наприкінці XIX у першій половині ХХ ст., відбулося гармонійне входження, 3 подальшою адаптацією в українську літературу традиційного образу французької національної героїні. Це явище було насамперед пов'язане із тим фактором, що Жанна д’Арк є символом патріотизму, національного духу, героїзму. Як відомо, саме героїзм є репрезентацією буття національної культури. Р. Комаров у своїй статті «Національний героїзм як предмет української філософської думки: проблема осмислення в поетичному тексті» зазначає: «український героїзм - чинник відповідної ідентичності, тому розуміння його природи розкриває змістовний і ціннісний аспект української національної культури, формує іï антропологічний ідеал, ідентифікація з яким і є процесом національної ідентифікації» [2, с. 64]. Тому не дивно, що саме в той історичний час, коли Україні потрібен був герой на кшталт Жанни д’Арк, до цього вже традиційного образу європейської літератури звернулися українські літературні діячі.

Творам Марії Загірньої (справжнє ім'я Марія Грінченко) [1863-1928] вчительки, письменниці, поетеси, перекладачки, авторки творів для дітей, а також науково-популярних праць, творчість якої мала народницьке спрямування, - притаманні лаконічність та змістовність, динамічність розповіді, жива народна мова. Письменниця створила цілісну україномовну бібліотеку науково-популярної серії 3 iсторії, географії, політекономії, медицини. Саме у цій серії з'явилося оповідання «За рідний край» [1], в шести частинах якого письменниця в хронологічному порядку описує долю Орлеанської діви.

Присвячуючи кожну з частин свого оповідання віховим подіям життя Жанни д’Арк, авторка іменує їх відповідним чином. Нескладно здогадатися, що центральним образом оповідання $\epsilon$ образ французької національної героїні. У творі М. Загірньої він найбільш розкритий і чітко прослідковується його динаміка. В оповіданні прочитується те, які життєві обставини вплинули на свідомість дівчини, що призвело до самонавіювання - ій стали чутися голоси, які спонукали їі йти рятувати 
Францію від чужоземних загарбників. Спочатку Жанна постає перед нами по-дитячому наївною, однак твердою у своїх переконаннях. Більш дорослою і серйозною бачимо ії під час виправи на Орлеан, рішучою i безстрашною на полі бою. Завдяки своїй хоробрості та незламній волі молода селянська дівчина (на що неодноразово у творі акцентує увагу М. Загірня, називаючи Жанну «мужичкою»), стає як для війська, так і для простого народу символом героїзму і відваги, а також співпереживання, співчуття і жертовності.

I хоча в оповіданні є інші персонажі, вони, на фоні образу Жанни, виглядають досить блідо. Наприклад, в досить негативних рисах змальовує М. Загірня образ спочатку дофіна, а потім короля Карла VII, негативна конотація притаманна образам опонентів Жанни, іï військовим противникам і суддям. Обмежившись буквально декількома словами на початку оповідання, характеризує авторка рідних героїні. Крім того, не можемо не зауважити наскрізний мотив, який буквально пронизує оповідання - мотив рідного краю, визволення його від загарбників.

Автор оповідання «Орлеанська дівчина» - Любомир Селянський (справжнє ім'я Іван Петришин) [1850-1912] - поет, народний учитель, січовий пісняр, автор поезій, оповідань і наукових статей, виступав полум'яним популяризатором козацько-січової ідеї, був творцем низки січових пісень із характерними мотивами соціального спрямування та ідеї соборності України.

Оповідання Любомира Селянського «Орлеанська дівчина» [3] складається із дванадцяти частин, в яких автор спершу дає коротку характеристику Жанни д’Арк та ії подвигу, так би мовити, знайомить читача із героїнею, а потім послідовно розповідає історію ії життя та смерті. Оповідання Л. Селянського багато в чому перегукується із оповіданням М. Загірньої. Очевидно, що або автор «Орлеанської дівчини» був знайомий із оповіданням «За рідний край», або що легенда про Жанну д’Арк на вітчизняних теренах мала лише одну таку версію. Та все ж стилістично твори різняться поміж собою. В оповіданні Л. Селянського, наприклад, маємо значно більше прямої мови та описів, аніж в оповіданні М. Загірньої, де можемо бачити більш лаконічний виклад подій. Крім того, $\epsilon$ суттєві відмінності у зображенні діючих персонажів. Жанна Л. Селянського, на відміну, від Жанни М. Загірньої, лагідніша, сумирніша, скромніша і побожніша, та й голоси, які вона чула, автор не трактує як самонавіювання, однак його Жанна б'ється на полі бою з мечем у руках. Хоча достеменно відомо, що історична Жанна д’Арк не вирізнялася красою, Л. Селянський у своєму оповіданні вказує на те, що вона була красунею. 
Показово, що Л. Селянський усю увагу закцентував у своєму оповіданні на постаті Жанни д’Арк. Однак, при цьому дещо виходить із тіні образ Карла VII, який тут, на відміну від оповідання М. Загірньої, де він змальований у різко негативних тонах, поданий дещо інакше, автор зображує його таким, що викликає до себе жалість і співчуття. Цікавою також $є$ та деталь, що обоє авторів оповідань про Жанну д’Арк подають у своїх творах лише дві точні дати з ііі біографії. Це - день коронації Карла VII у Реймсі (27 липня 1429 р.) та день смерті Орлеанської діви у Руані (30 квітня 1431 р.). Тим не менш, це не єдине співпадіння. В обох оповіданнях бачимо вже з перших сторінок натяки на страту Жанни на вогнищі, які автори вкладають в уста батька героїні та англійського лицаря Талбота. Однаковими також $є$ пункти обвинувачення, які висувають Жанні iii судді. Завершуючи свої оповідання, автори стверджують, що французи завжди шануватимуть світлу пам'ять про Жанну, як про люблячу доньку своєї батьківщини, яка заради їі свободи не пошкодувала власного життя.

Отже, як бачимо, образ славної доньки французького народу гармонійно увійшов та адаптувався в українському красному письменстві першої половини XX ст., будучи безпосередньо пов'язаним із героїчними мотивами української літератури того часу і презентував собою у цій літературі тип героя-пробуджувача, який веде свій народ до визволення 3-під ярма і національного розвитку.

\section{Література:}

1. Загірня М. За рідний край. Київ : Видання Т-ва «Просвіта», 1908. $46 \mathrm{c}$.

2. Комаров Р. Національний героїзм як предмет української філософської думки: проблема осмислення в поетичному тексті. Наукові записки. Київ : Національний університет «Києво-Могилянська академія», 2006. Т. 49. Теорія та історія культури. С. 63-67.

3. Селянський Л. Орлеанська дівчина. Львів: Видання Т-ва «Просвіта», 1912. $46 \mathrm{c}$.

4. Шевчук М. Аспекти входження «вічних» сюжетів у національну літературу. Наукові записки. Київ : Національний університет «КиєвоМогилянська академія», 1998. Т. 4. Філологія. С. 48-51.

5. Шевчук М. Національно-специффічні засади обробки традиційних сюжетів (на матеріалі творчості Лесі Украӥнки) : автореф. дис... канд. філол. наук: 10.01.06. Київ : Інститут літератури ім. Т. Г. Шевченка НАН України, 2000. 20 с. 